\title{
Future changes in extreme precipitation in central Serbia
}

\author{
Ranka Erić $^{*}$, Ratko Kadović ${ }^{1}$, Vladimir Đurđević ${ }^{2}$, Vesna Đukić ${ }^{1}$ \\ ${ }^{1}$ University in Belgrade, Faculty of Forestry, Kneza Višeslava 1, 11030 Belgrade, Serbia. \\ ${ }^{2}$ University of Belgrade, Faculty of Physics, Institute of Meteorology, Dobračina 16, 11000 Belgrade, Serbia. \\ * Corresponding author. Tel.: + 38111 3053957. E-mail: ranka.eric@sfb.bg.ac.rs
}

\begin{abstract}
This paper presents the results of a study focused on the projected changes in extreme precipitation during the 21 st century in Central Serbia. The changes are investigated on the basis of historical and modelled data sets of daily precipitation. The historical observation data were recorded at 18 synoptic weather stations in Central Serbia and modelled data were extracted from the regional climate model EBU-POM (Eta Belgrade University-Princeton Ocean Model) under the A1B scenario. The average number of days in a year with precipition $\geq 20,30,40$ and $50 \mathrm{~mm}$ (R20, $\mathrm{R} 30, \mathrm{R} 40$ and R50), the share of daily precipitation above the 20, 30, 40 and $50 \mathrm{~mm}$ (P20, P30, P40, P50) in the total annual precipitation and the monthly distribution of these heavy daily precipitation are used as indices of changes in extreme precipitation. These indices, for the three periods 2011-2040, 2041-2070 and 2071-2100, are determined and compared with those obtained for the historical reference period 1961-1990. The results have shown that the main changes in extreme precipitation in Central Serbia will be in their spatial distribution, and the uncertainty of the occurrence of extreme events will decrease. In the future the increase will be more pronounced than the decrease of these indices. We strongly emphasize the benefit of this paper for both the prevention of natural disasters in the study area and for the improvement of the regional climate model.
\end{abstract}

Keywords: Future extreme precipitation; Climate changes; Regional climate model; Central Serbia.

\section{INTRODUCTION}

The whole world has experienced different natural catastrophic events caused by climate changes. Extreme weather, fuelled by climate change, struck every corner of the globe in 2019 (Kramer and Ware, 2019). Hirabayashi et al. (2008) found that the frequency of floods in many regions of the world has increased. Riverbank erosion is also a serious hazard that directly or indirectly causes the suffering of millions of people. Aktar (2013) shows that climate change will play a significant role in riverbank erosion. All of the disasters caused economic damage and also took away a huge number of humans lives. Because of that, many worldwide studies of climate changes and their impact on different aspects of the environment, have been performed so far, and their number is still growing today (Aktar, 2013; Cavicchia et al., 2018; Cooper, 2019; DeGateano and Castellano, 2017; Fotso-Nguemo et al., 2019; Huang, Wang et al., 2018; Soltani et al., 2016; Tan et al., 2017). Among them, those related to temperature and precipitation extremes play an important role. The relationship between extreme precipitation and the corresponding temperature is of great importance for predicting precipitation extremes in the future, given the rapid increase of global warming (Yang et al., 2020). The most important conclusion of the studies conducted were the increases in magnitude, frequency, and probability of the occurrence of extreme temperature and extreme precipitation events (Alexander et al., 2006; Bocheva et al., 2010; Harpa et al., 2019; Huang, Wang et al., 2018; Janković et al., 2019; Jiang et al., 2012; Kjellström and Ruosteenoja, 2007; Li et al., 2019; Tramblay and Somot, 2018; Vuković et al., 2018). Kjellström and Ruosteenoja (2007) investigated simulated changes in the precipitation over the Baltic Sea at the end of the 21 st century and the precipitation is projected to increase in the Baltic Sea area, especially during winter. For extreme precipitation indices in China, the end of the twenty-first century is expected to have more frequent and more intense extreme precipitation (Jiang et al., 2012). One of the study in Hungary shows that the annual sum is not likely to change significantly in the region, but the seasonal precipitation is projected to change significantly during the 21 st century (Pongracz et al., 2011).

Schneider et al. (2013) evaluated the impact of climate change on river flow regimes in Europe and found that on the European scale, climate change can be expected to significantly modify flow regimes, especially in the Mediterranean and boreal climate zones. For Balkan areas, society relevant strong impacts of such extreme precipitation changes could be expected in particular concerning flood-related damages (Tramblay and Somot, 2018). Therefore, there are different studies about climate changes and their environmental impact in Serbia and in the neighboring countries. They are related to extreme temperatures, precipitation, soil temperatures, soil moisture, droughts and wet periods (Bocheva et al., 2010; Gocić and Trajković, 2013, 2014; Harpa et al., 2019; Janković et al., 2019; Kržič et al., 2011; Mihailović et al., 2016; Pongracz et al., 2011; Unkašević and Tošić, 2011; Vuković et al., 2018). Kržič et al. (2011) have shown an overall increase in the surface air temperature of about $2{ }^{\circ} \mathrm{C}$ and a decrease in seasonal precipitation sums of about $13 \mathrm{~mm}$ in Serbia. Unkašević and Tošić (2011) found that the mean annual precipitation on the wettest day during the 20th century across Serbia increased by nearly 9\%. Gocić and Trajković (2013) analysed changes in precipitation using Mann-Kendall and Sen's slope estimator statistical tests during the period 1980-2010. These analyses are of great importance for water resources planning and for the improvement of water resources management in the study area. Janković et al. (2019) have shown significant decrease of heating degree days (HDD) and increase of cooling degree days (CDD) in the 21st century over Serbia. This study should help the policy of energy management and planning in Serbia and in 
the region. Consequently, any future analysis should be helpful for understanding and decreasing of negative climate change impacts on natural and anthropogenic systems.

The territory of Serbia was the study area for several previously conducted studies on historical and future changes in precipitation indices (Gocić and Trajković, 2013; Kržič et al., 2011; Unkašević and Tošić, 2011; Vuković et al., 2018). The mentioned papers mostly describe changes in average monthly, seasonal or annual precipitation, which have been so far. Climate change can affect the intensity and frequency of precipitation and cause an increase in extreme precipitation. On the other side, increases in extreme precipitation may not always lead to an increase in total precipitation over a season or over the year - just that precipitation is occurring in more intense events. However, extreme precipitation analyses are very important due to the potential impacts of extreme precipitation as soil erosion, an increase in flood risk due to heavy rain, etc. According to that, this paper presents the results of a study focused on the projected changes in extreme precipitation in Central Serbia during three periods in the 21st century: 20212040, 2041-2070, and 2071-2100. There are many contributions of these results. The most important are the possibility of predicting future flood events and reducing the risk of their occurrence in Central Serbia. The knowledge of the climate change projections in extreme precipitation is an important decision support tool for civil protection and the prevention major of natural disasters. More details about the data, methods and results can be found in the next sections.

\section{DATA AND METHODS}

\section{Study area}

The Republic of Serbia is located on the Balkan Peninsula between latitudes $41^{\circ}-47^{\circ} \mathrm{N}$ and longitudes $18^{\circ}-23^{\circ} \mathrm{E}$. Central
Serbia has an area of $55,965 \mathrm{~km}^{2}$, hilly and mountainous configuration intersected with local river basins (Figure 1). The climate of Central Serbia is moderate continental with some specific characteristics, caused by the geographic location, relief, terrain exposure, etc. The mean annual temperature for areas with an altitude of up to $300 \mathrm{~m}$ is $10.9^{\circ} \mathrm{C}$, and for areas with an altitude of $300 \mathrm{~m}$ to $500 \mathrm{~m}$ around $10.0^{\circ} \mathrm{C}$. In mountainous areas with an altitude of over $1000 \mathrm{~m}$, the average annual temperatures are around $6.0{ }^{\circ} \mathrm{C}$, and at an altitude of over $1500 \mathrm{~m}$ around $3.0{ }^{\circ} \mathrm{C}$. Annual precipitation generally rises with altitude. In lower regions, it ranges in the interval from 540 to $820 \mathrm{~mm}$. Areas with altitudes of over $1000 \mathrm{~m}$ receive on average 700 to $1000 \mathrm{~mm}$, and some mountain tops in southwestern Serbia up to $1500 \mathrm{~mm}$. The major part of Central Serbia has the continental precipitation regime, with a peak in the earlier summer period, except for southwest, which receives the highest precipitation in autumn. May-June is the rainiest month, with an average of 12 to $13 \%$ of total annual amount. February and October have the lowest precipitation (Republic Hydrometeorological Service of Serbia, 2020).

\section{Data}

Both historical and modelled data were used in this study. The historical data are daily precipitation time series from 18 meteorological stations over a 30-year period (1961-1990). This period is the reference period for this study. Technical and quality controls for these measurements were made by the National Meteorological Service of Serbia. The spatial distribution of the weather stations considered is presented in Figure 1 and their geographical coordinates are listed in Table 1.

Except for the direct observation data from stations (MSTAT), there are also E-OBS daily precipitation data (Cornes et al., 2018) for all 18 stations over the reference period

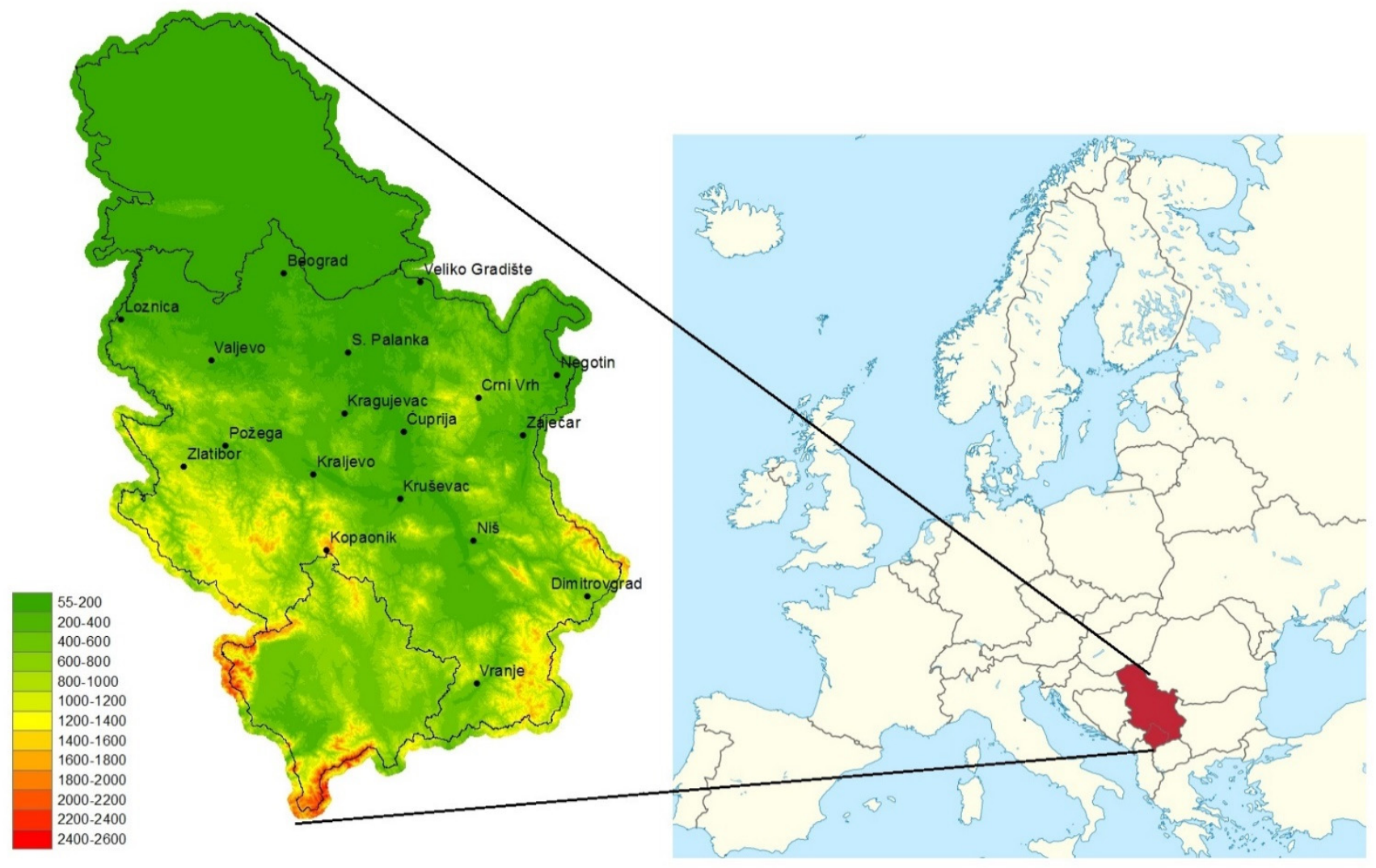

Fig. 1. Location of Serbia in the Europe, altitude of the terrain in Serbia (m a.s.1.) and spatial distribution of the meteorological stations. 
Table 1. Geographical descriptions of the synoptic stations used in the study.

\begin{tabular}{|l|c|c|c|}
\hline Station name & $\begin{array}{c}\text { Longitude } \\
(\mathrm{E})\end{array}$ & $\begin{array}{c}\text { Latitude } \\
(\mathrm{N})\end{array}$ & $\begin{array}{c}\text { Elevation } \\
(\mathrm{m} \text { a.s.l. })\end{array}$ \\
\hline 1. Belgrade & $20^{\circ} 28^{\prime}$ & $44^{\circ} 48^{\prime}$ & 132 \\
\hline 2. Ćuprija & $21^{\circ} 22^{\prime}$ & $43^{\circ} 56^{\prime}$ & 123 \\
\hline 3. Crni Vrh & $21^{\circ} 58^{\prime}$ & $44^{\circ} 08^{\prime}$ & 1,027 \\
\hline 4. Dimitrovgrad & $22^{\circ} 45^{\prime}$ & $43^{\circ} 01^{\prime}$ & 450 \\
\hline 5. Kraljevo & $20^{\circ} 42^{\prime}$ & $43^{\circ} 43^{\prime}$ & 215 \\
\hline 6. Kragujevac & $20^{\circ} 56^{\prime}$ & $44^{\circ} 02^{\prime}$ & 185 \\
\hline 7. Kopaonik & $20^{\circ} 48^{\prime}$ & $43^{\circ} 17^{\prime}$ & 1,711 \\
\hline 8. Kruševac & $21^{\circ} 21^{\prime}$ & $43^{\circ} 34^{\prime}$ & 166 \\
\hline 9. Loznica & $19^{\circ} 14^{\prime}$ & $44^{\circ} 43^{\prime}$ & 121 \\
\hline 10. Negotin & $22^{\circ} 33^{\prime}$ & $44^{\circ} 14^{\prime}$ & 42 \\
\hline 11. Niš & $21^{\circ} 54^{\prime}$ & $43^{\circ} 20^{\prime}$ & 204 \\
\hline 12. Požega & $20^{\circ} 02^{\prime}$ & $43^{\circ} 50^{\prime}$ & 310 \\
\hline 13. S. Palanka & $20^{\circ} 57^{\prime}$ & $44^{\circ} 22^{\prime}$ & 121 \\
\hline 14. Valjevo & $19^{\circ} 55^{\prime}$ & $44^{\circ} 17^{\prime}$ & 176 \\
\hline 15. Veliko Gradište & $21^{\circ} 31^{\prime}$ & $44^{\circ} 45^{\prime}$ & 80 \\
\hline 16. Vranje & $21^{\circ} 55^{\prime}$ & $42^{\circ} 33^{\prime}$ & 432 \\
\hline 17. Zaječar & $22^{\circ} 17^{\prime}$ & $43^{\circ} 53^{\prime}$ & 144 \\
\hline 18. Zlatibor & $19^{\circ} 43^{\prime}$ & $43^{\circ} 44^{\prime}$ & 1,028 \\
\hline
\end{tabular}

(1961-1990). The E-OBS dataset is a gridded product providing daily precipitation data obtained through interpolating station observations on a regular $10 \mathrm{~km}$ resolution grid.

The many future changes analyses in extreme precipitation were based on the simulations of regional climate models. Most of the regional climate model validations show that they are performing reasonably well in reproducing the spatial patterns of observed precipitation (DeGateano and Castellano, 2017; Fotso-Nguemo et al., 2019; Harpa et al., 2019; Janković et al., 2019; Jiang et al., 2012; Kjellström and Ruosteenoja, 2007; Li et al., 2019; Mihailović et al., 2016). Therefore, they provide a reliable basis for the forecasting of future precipitation and other climate indices. So, we employed the output of the EBUPOM coupled regional climate model (RCM) for the 19612100 period according to the SRES-A1B scenario (MA1B). The horizontal resolution of the regional model is $25 \mathrm{~km}$ (Đurđević and Rajković, 2008; Đurđević, 2010). A detailed description of the A1B scenario can be found in the IPCC Special Report (The Special Report on Emissions Scenarios (SRES), Nakićenović and Swart, 2000).

\section{Method}

At the beginning of this analysis, model results (MA1B) were validated against the observed data from 18 synoptic stations (MSTAT and E-OBS) over the reference period (19611990). The coefficient of determination $\left(\mathrm{R}^{2}\right)$, the Pearson correlation coefficient (r) (Eq. (2)) and root mean square error (RMSE) (Eq. (3)) were adopted for the model evaluation. The Pearson correlation coefficient (Eq. (2)) is used to measure the strength of a linear association between modelled and observed data. The value $r=1$ means a perfect positive correlation and the value $r=-1$ means a perfect negative correlation. When the Pearson's coefficient is used as a decision-making tool, the following statistical inference is common: $(0.00,0.40)$ weak correlation; $(0.40,0.75)$ moderate correlation; $(0.75,0.85)$ is a good correlation, and $(0.85,1.00)$ is an excellent correlation. The coefficient of determination $\mathrm{R}^{2}$ (Eq. (1)) describes the proportion of the total statistical variance in the observed dataset that can be explained by the model. It ranges from 0.0 (poor model) to 1.0 (perfect model). Eq. (3) is used to calculate the root mean squared error (RMSE). This metric records in real units the level of overall agreement between the observed and modelled datasets. It is a non-negative metric that has no upper bound and for a perfect model the result would be zero (Dawson et al., 2007).

$$
\begin{aligned}
& R^{2}=\left[\frac{\sum_{i=1}^{N}\left(R_{o b s, i}-\bar{R}_{o b s}\right)\left(R_{\mathrm{mod}, i}-\bar{R}_{\mathrm{mod}}\right)}{\sqrt{\sum_{i=1}^{N}\left(R_{o b s, i}-\bar{R}_{o b s}\right)^{2} \sum_{i=1}^{N}\left(R_{\mathrm{mod}, i}-\bar{R}_{\mathrm{mod}}\right)^{2}}}\right]^{2} \\
& r=\frac{\sum_{i=1}^{N}\left(R_{o b s, i}-\bar{R}_{o b s}\right)\left(R_{\mathrm{mod}, i}-\bar{R}_{\mathrm{mod}}\right)}{\sqrt{\sum_{i=1}^{N}\left(R_{o b s, i}-\bar{R}_{o b s}\right)^{2} \sum_{i=1}^{N}\left(R_{\mathrm{mod}, i}-\bar{R}_{\mathrm{mod}}\right)^{2}}} \\
& R M S E=\sqrt{\frac{\sum_{i=1}^{N}\left(R_{o b s, i}-R_{\mathrm{mod}, i}\right)^{2}}{N}}
\end{aligned}
$$

where $R_{o b s, i}$ is indice of the observed data, $R_{\text {mod, } i}$ is indice of the modelled data, $\bar{R}_{\text {obs }}$ is the average value of the observed data indices, $\bar{R}_{\text {mod }}$ is the average value of the modelled data indices, $N$ is the total number of observations.

Within the model validation, the extreme precipitation indices of the observed and modelled data are determined and compared. The threshold for heavy precipitation events in Serbia is in the range of 36.6-52.5 mm (Jovanović et al., 2018). Based on this, the indices which are used within this study are determined. The indices are the average number of days in a year with precipitation amounts of $\geq 20,30,40$ and $50 \mathrm{~mm}$ (R20, R30, R40, R50, respectively). In order to determine future changes in extreme precipitation, two more indices were developed. They are: the share of daily precipitation $\geq 20,30$, 40 and $50 \mathrm{~mm}$ (P20, P30, P40, P50) within the total annual precipitation, and the monthly distribution of these heavy daily precipitation. These three indices were determined for the future modelled data, and also for the observed data. The changes are detected by comparing these two groups of indices.

\section{RESULTS AND DISCUSSION Validation of the model}

The results of the model validation are shown in the following figures and graphs.

Figures 2 and 3 show that E-OBS is in better accordance with the MA1B data than MSTAT. That was probably because the E-OBS and MA1B data have resolutions, and these data are derived based on the measured data. On the other hand, the MSTAT data are measured data from one location (meteorological station) and have more precise values. The values of $r$ indicate that there are medium-strong to very-strong data correlations between the MSTAT and the E-OBS and MA1B data. The values of the coefficient of determination (most are above 0.5 ) indicate that a significant part of data variance is explained by the model. RMSE score better results for E-OBS data than for MSTAT data. The model validation shows that the regional climate model reproduces the spatial variability very well, with a slightly lower magnitude accuracy of these indices (R20, R30, $\mathrm{R} 40$, and R50) for the points at the meteorological stations. 


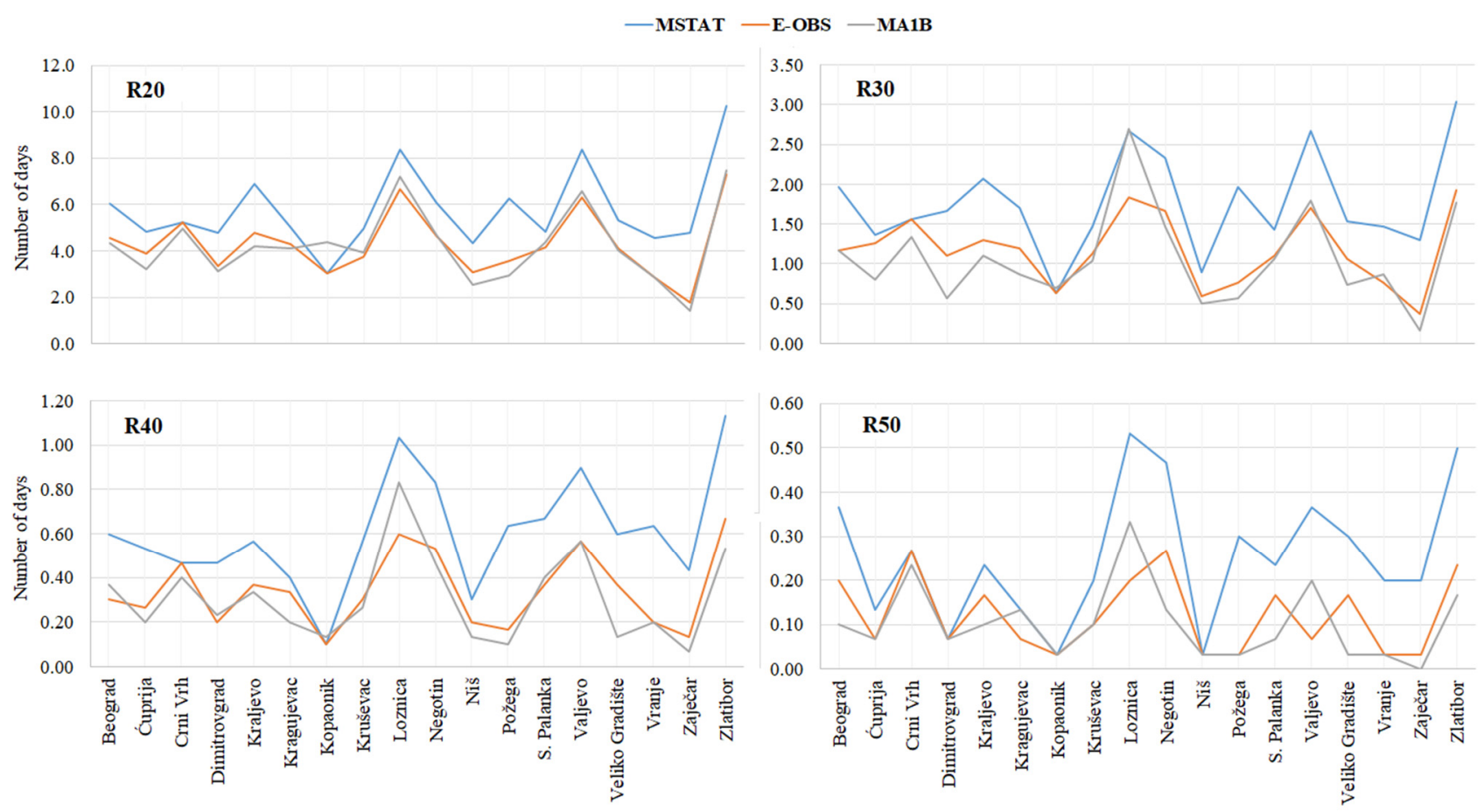

Fig. 2. Average number of days in a year with precipitation amounts $\geq 20,30,40$ and $50 \mathrm{~mm}$ for 18 synoptic stations in Central Serbia over the reference period 1961-1990; MSTAT - observed values on meteorological stations, E-OBS - E-OBS gridded climatology from European Climate Assessment \& Dataset (ECA\&D) project, MA1B - modelled values from the EBU-POM model projection for A1B scenario.



Fig. 3. Modelled vs. observed data: Comparation of the average number of days in a year with precipitiation amounts above $20,30,40$ and $50 \mathrm{~mm}$, root mean squared error, the coefficient of correlation and the coefficient of determination between MA1B and MSTAT data, MA1B and E-OBS data. 
The correlation weakens with an increasing amount of precipitation. The strongest correlation was found for R20 and the weakest for R50. According to these results, the E-OBS data have a better performance in relation to the MSTAT, so they are used for further analysis of the future changes in extreme precipitation. The spatial distributions of the R20, R30, R40 and R50 during the reference period are shown in Figure 4. The historical data show that the west and northeast parts of Central Serbia have more days with heavy precipitation than southern and southeastern parts. The maximum values of R20, R30, and R40 are recorded in the west. However, the maximum of R50 (very heavy precipitation) is found in the northeastern part of the observed area.

\section{Future changes in extreme precipitation indices}

The future evolution of extreme precipitation indices in Central Serbia revealed different results depending on the indices. Some of them indicate a constant increase or even a small decrease (R20 and R30) until the end of the century, while others indicate a significant increase in frequency or intensity (R40 and R50). Similar results were obtained in similar analyses performed in the surrounding area and in other parts of the world (Jiang et al., 2012; Pongracz et al., 2011; Tramblay and Somot, 2018). Detailed results of this study are presented in the following sections (all values $<1$ characterize the decrease, if they are equal to 1 then they indicate no change and those that are $>1$ indicate an increase).

\section{Changes detected in the R20, R30, R40 and R50}

Figure 5 shows that the spatial distribution of daily precipitation $\geq 20 \mathrm{~mm}$ in Central Serbia will change during the $21 \mathrm{st}$ century. During the reference period, most days with precipitation $\geq 20 \mathrm{~mm}$ were in the western part of the study area. In the future there will be a rotation, i.e. it will increase and decrease in areas where R20 was low and high, respectively. The increase will be more noticeable in the south (at the Kopaonik
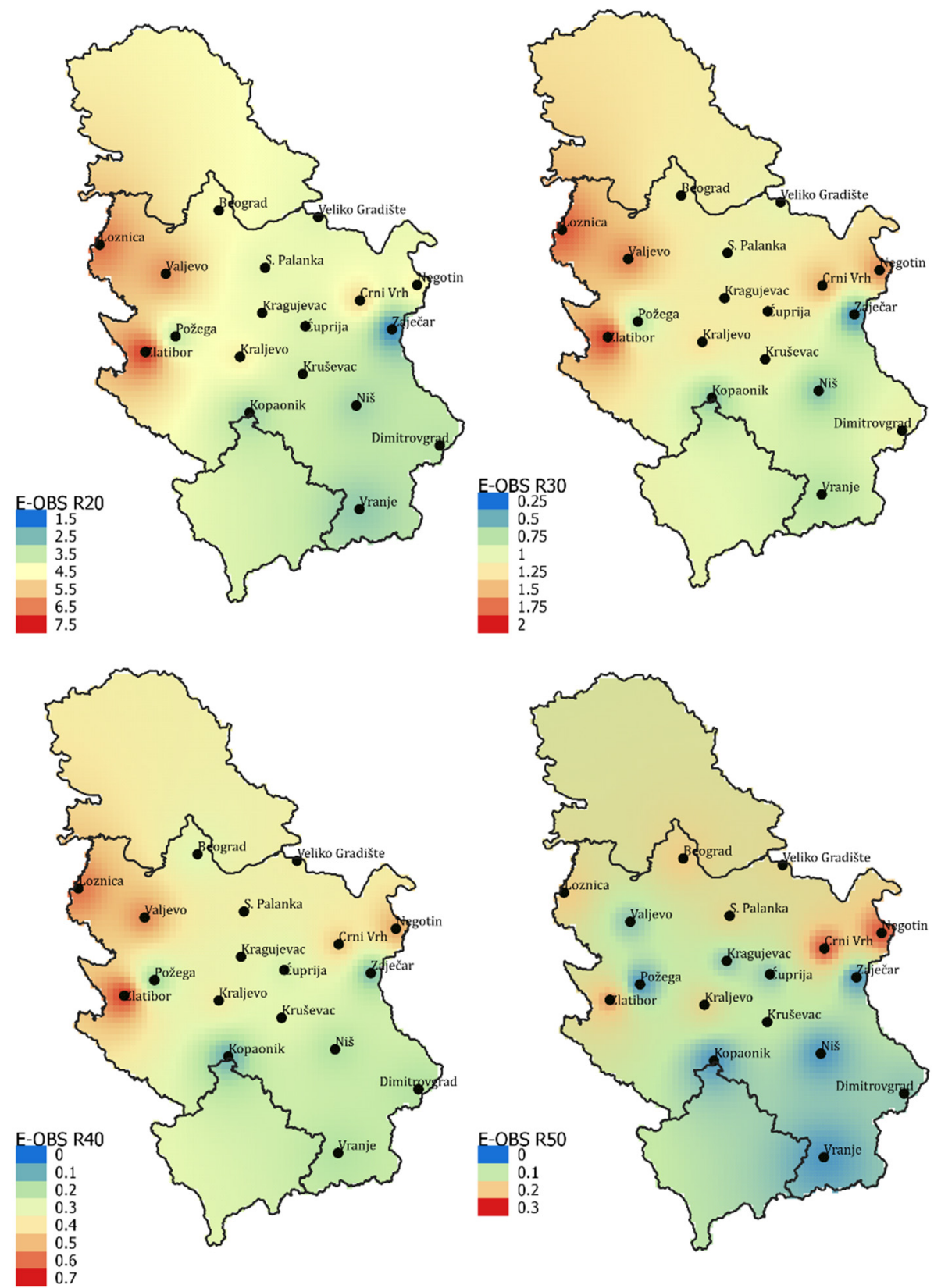

Fig. 4. Spatial distribution of R20, R30, R40 and R50 during the reference period 1961-1990 (E-OBS data). 

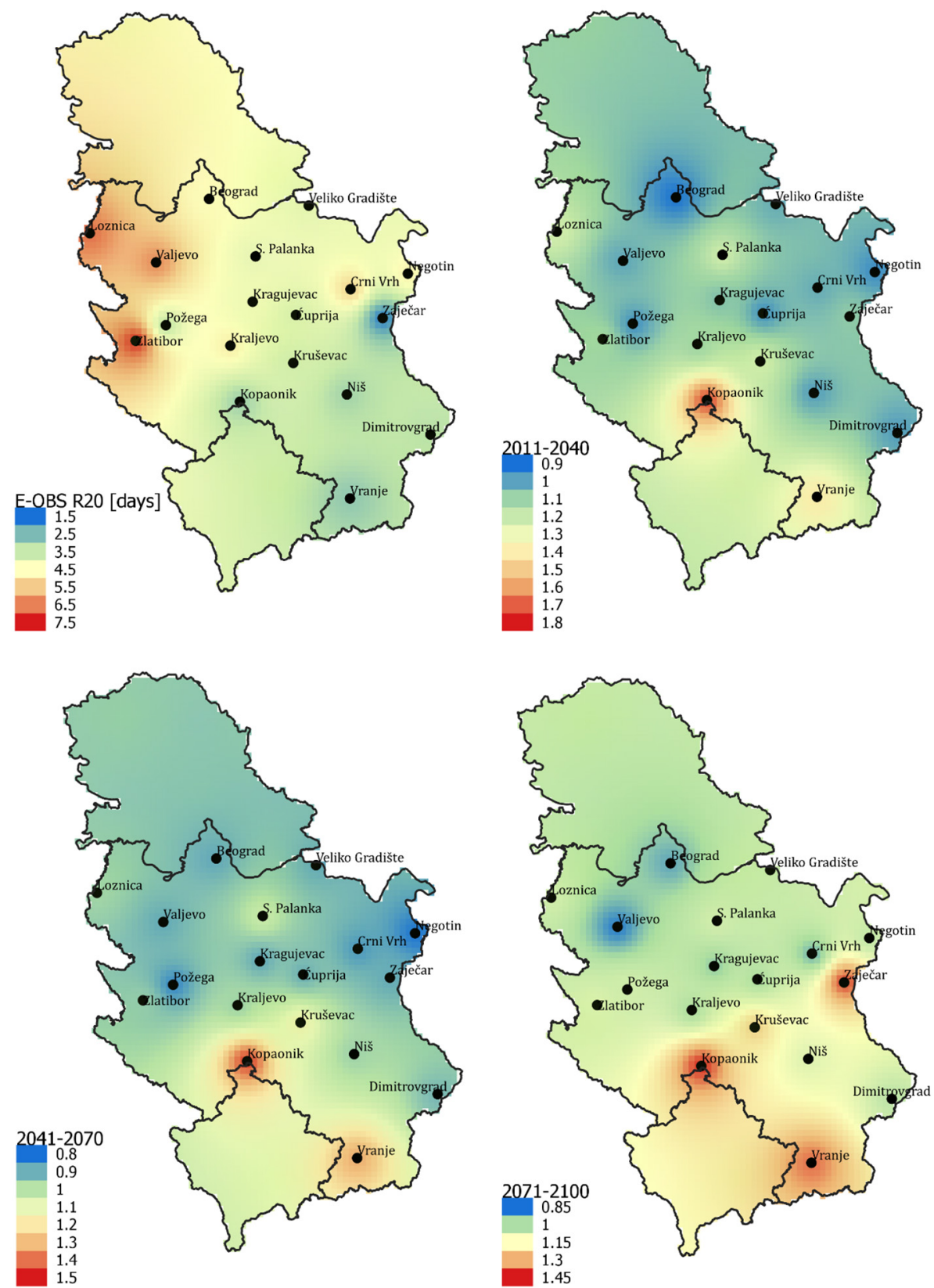

Fig. 5. Projected changes (times , $\mathrm{x}^{\prime)}$ ) in the average number of days in a year with precipitation amounts $\geq 20 \mathrm{~mm}$ (R20) compared to the historical data (E-OBS R20; 1961-1990) for 18 selected locations in Central Serbia through the 21st century (period 2011-2040; period 2041-2070 and period 2071-2100).

and Vranje stations) during the first two periods (2011-2040 and 2041-2070). The last period (2071-2100) is characterized by an increase in R20. It covers the area from south to east, where the Zaječar station stands out (during the reference period Zaječar had the lowest R20). The largest increase of $80 \%$ in R20 is expected in the period 2011-2040. The decrease of R20 is noticeable in most of the area during the first two periods, and the maximum is $20 \%$. The average intensity of R20 change for the whole analyzed area has a variable trend. First, there is an increase of this parameter followed by its decrease through the middle of the century, and at the end of the century there is another increase of R20.

The change of R30 (Figure 6) is very similar to the change of R20. An increase of R30 occurs in the part of the area with the lowest number of days with precipitation $\geq 30 \mathrm{~mm}$ in the past and vice versa. The average change intensity indicates that this parameter increases in the whole area and this change varies over time. Namely, the highest intensity of change should be at the end of the century, and the lowest one is in the middle of the century. The maximum increase is about $110 \%$ $(2.1 \mathrm{x})$, and the highest decrease is about $40 \%$. The maximum increase is noticed at Kopaonik, Loznica, Zaječar and Niš, and the maximum decrease of R30 is observed for Dimitrovgrad.

Future changes in R40 do not follow a certain pattern. During the three future periods, the increase in R40 covers more and more parts of the analysed area (Figure 7). The locations of the most intense changes are changing. Vranje stood out at the beginning of the century, Loznica and Belgrade in the middle 

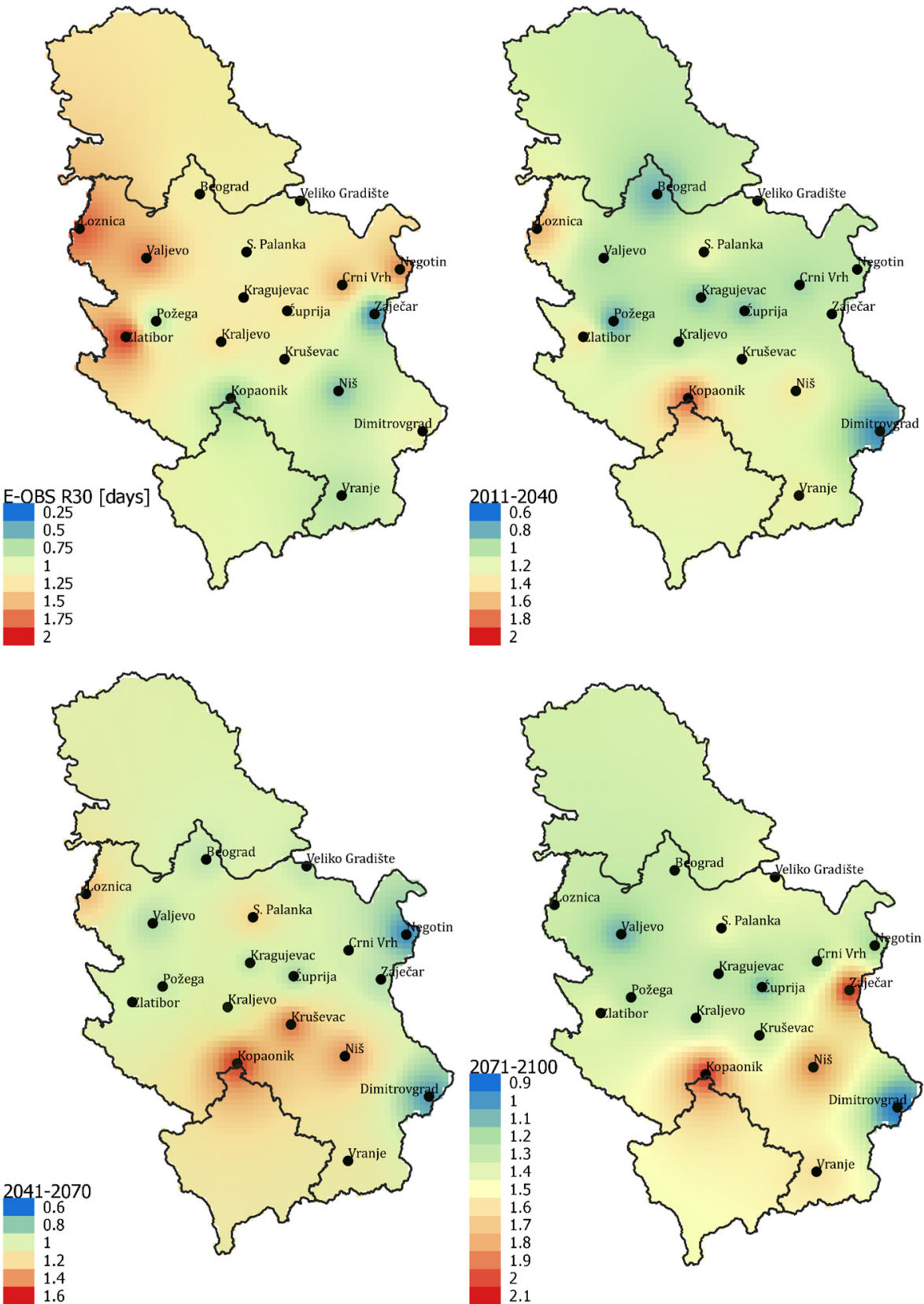

Fig. 6. Projected changes (times , $\mathrm{x}^{\prime)}$ ) in the average number of days in a year with precipitation amounts $\geq 30 \mathrm{~mm}$ (R30) compared to the historical data (E-OBS R30; 1961-1990) for 18 selected locations in Central Serbia during the 21st century (period 2011-2040; period 2041-2070 and period 2071-2100).

of the century, and at the end of the century the biggest increase is expected for Kopaonik (even 5 times „,X“). Compared to the reference period, a decrease is also observed for Požega and it reached up to $80 \%$.

The change intensity increases as the precipitation amount increases. The most intensive increase of R50 is expected at the end of the analysed period, up to 9x (Figure 8). The southern part of Central Serbia is the most critical (Vranje and Kopaonik), while at the beginning of the 21 st century the most critical points were in the west (Loznica and Valjevo). On the other hand, the decrease is more represented than the increase of R50 at the beginning of the 21 st century. However, the number of stations with a daily precipitation amount $\geq 50 \mathrm{~mm}$ increases over time.
These changes are in line with previous researches. Tramblay and Somot (2018) showed that in the Mediterranean, future changes in the spatial distribution of extreme precipitation are expected, as well as a decrease and increase in their occurrence. The end of the twenty-first century is expected to have a more frequent and more intense extreme precipitation in Central Serbia. Such results were also obtained in another study for the relevant study area (Jiang et al., 2012).

Changes detected in the monthly distribution of R20, R30, R40 and $R 50$

The presented results (Figure 9) indicate that future changes in the monthly distribution of these four indicators (R20, R30, 

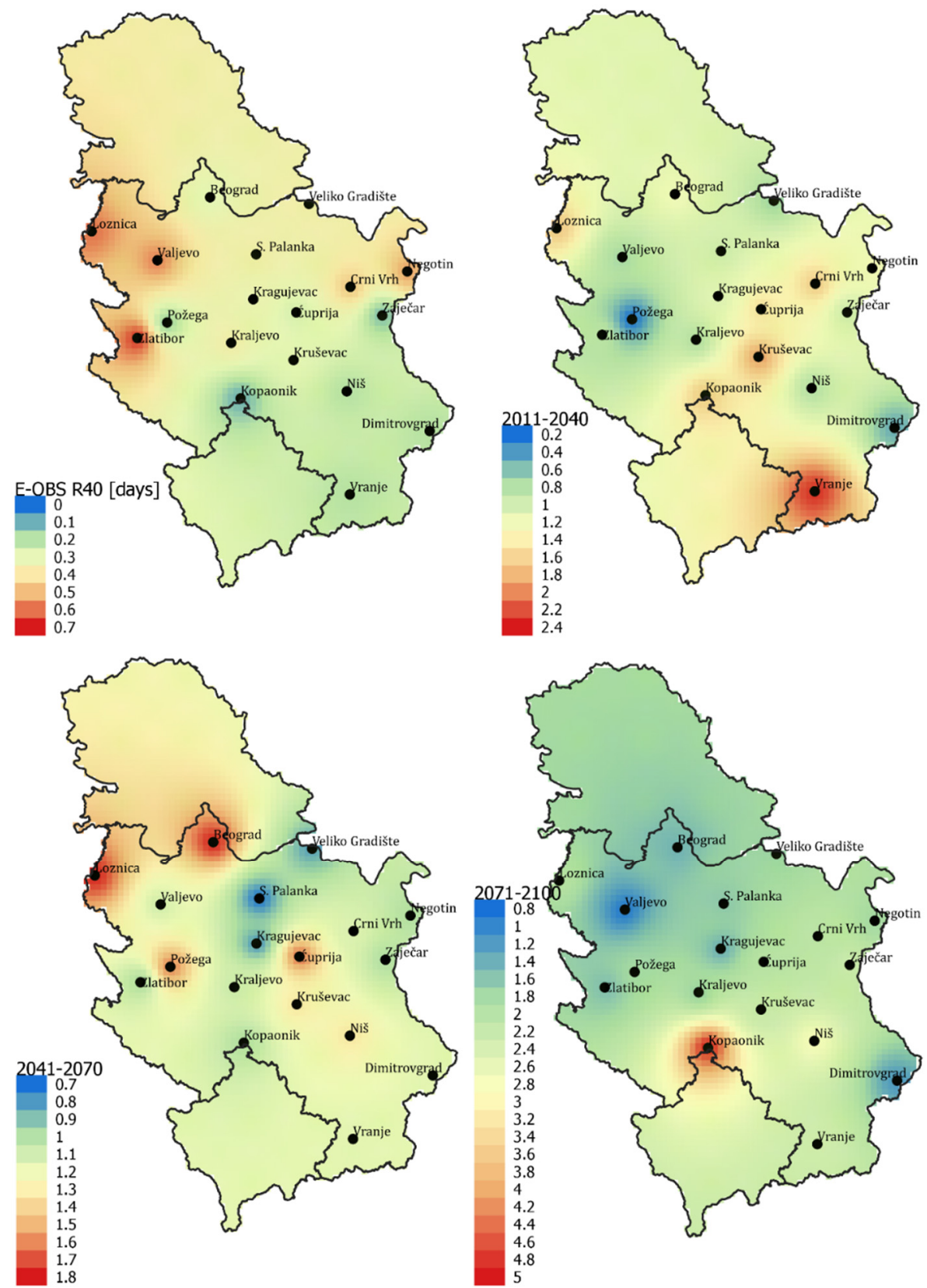

Fig. 7. Projected changes (times , $\mathrm{x}^{\prime \prime}$ ) in the average number of days with precipitation amounts $\geq 40 \mathrm{~mm}$ (R40) compared to the historical data (E-OBS R40) for 18 selected locations in Central Serbia during the 21st century (period 2011-2040; period 2041-2070; period 2071-2100).

R40, R50) are very similar. During the reference period, the highest values of R20 and R30 were in June, while for R40 and R50 the situation was slightly different. This confirms the fact that June has been one of the rainiest months in Serbia so far (Republic Hydrometeorological Service of Serbia, 2020). Extreme precipitation $\geq 40 \mathrm{~mm}$ is most often observed in August, then in July and June. Precipitation $\geq 50 \mathrm{~mm}$ most often occurs in October, June and August. In the period 1961-1990, the uncertainty of the event occurrence increases with the precipitation amount increase. Namely, the probability of occurrence of R40 and R50 is almost equal over several months, which is not the case with R20 and R30. In the near future, extreme precipitation is mostly expected in July (around 40-55\%), and the rest is distributed during the other months of the year. In the period from 2041-2070, the majority of days with precipitation higher than 20,30, 40 and $50 \mathrm{~mm}$ are expected in July, August and October. The results show (Figure 9) that October will be the month with the largest number of days with extreme precipitation (R20, R30, R40 and R50) in the last period of the 21 st century. About $70 \%$ of the total number of extreme events in the year will occur in October. This indicates that the uncertainty of extreme precipitation occurrence will decrease during the 21 st century. This change is also typical in the area of neighboring Hungary. There, summer precipitation is projected to decrease significantly during the 21 st century, autumn and winter precipitation amounts are projected to increase (Pongracz et al., 2011). 

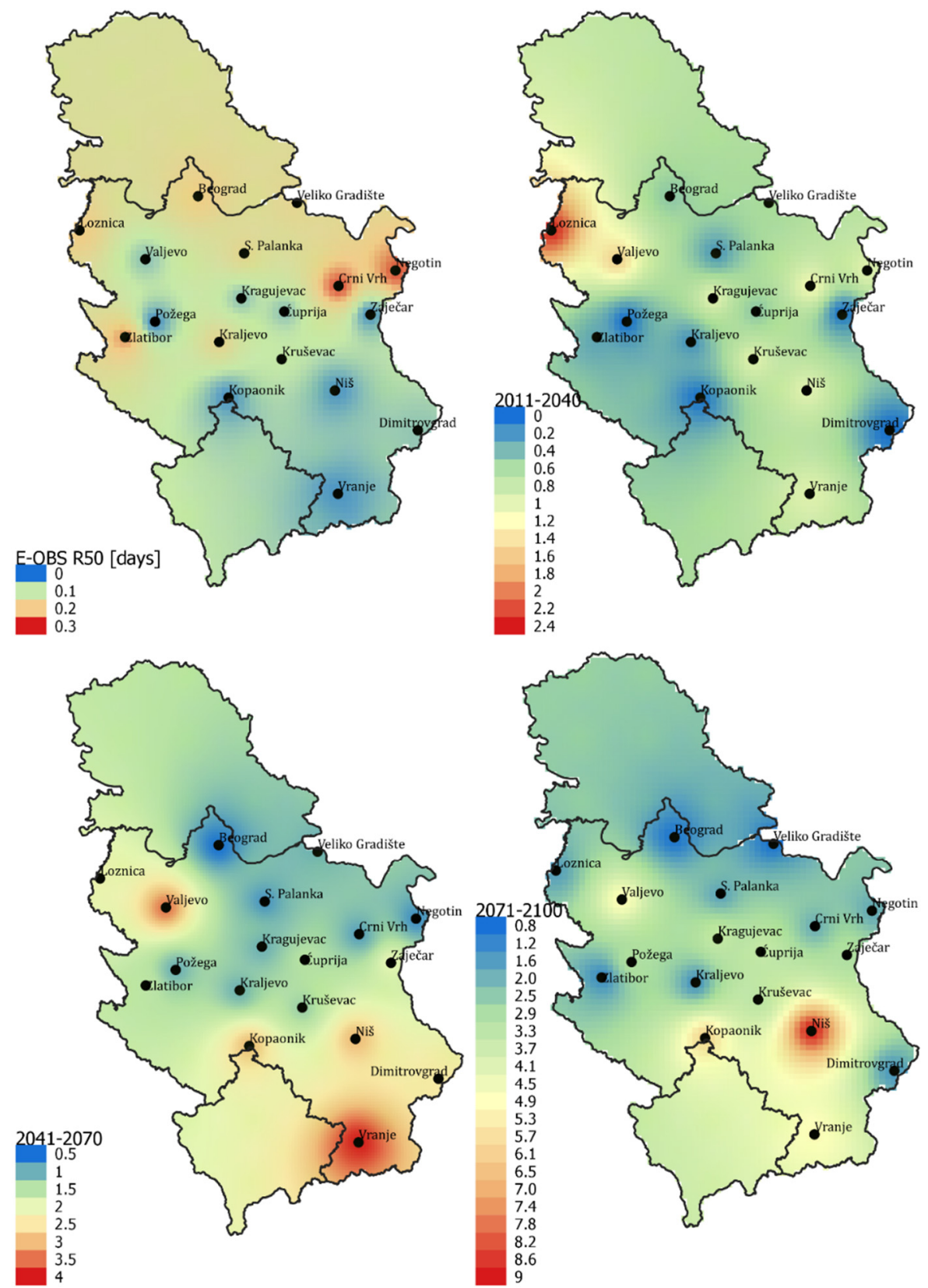

Fig. 8. Projected changes (times , $\mathrm{X}^{“)}$ in the average number of days with precipitation amounts $\geq 50 \mathrm{~mm}$ (R50) compared to the historical data (E-OBS R50) for 18 selected locations in Central Serbia during the 21st century (period 2011-2040; period 2041-2070; period 2071-2100).

Changes detected in the share of precipitation $\geq 20,30,40$ and $50 \mathrm{~mm}$ within the annual precipitation

During the reference period, the average shares of daily precipitation in the total annual precipitation were about $17 \%$, $6.6 \%, 2.5 \%$ and $1.1 \%$ for daily precipitation $\geq 20 \mathrm{~mm}, \geq 30$ $\mathrm{mm}, \geq 40 \mathrm{~mm}$, and $\geq 50 \mathrm{~mm}$, respectively (Figure 10). According to the results of the modelled data analysis, the average share of this precipitation in the annual precipitation amount is expected to increase in the future. The average share of $\mathrm{P} 20$ will be about $20 \%$, of $\mathrm{P} 30$ about $9 \%$, of $\mathrm{P} 40$ about $4 \%$, and of $\mathrm{P} 50$ about $1.8 \%$ of the total annual precipitation. The average increase in $\mathrm{P} 20, \mathrm{P} 30$, and $\mathrm{P} 40$ is around $1.2 \mathrm{x}, 1.3 \mathrm{x}$, and $1.55 \mathrm{x}$, respectively. The share of P50 decreases at the beginning of the 21 st century, and then from 2041-2100 it is expected to increase on average up to $2.45 \mathrm{x}$. Table 2 shows the individual increase or decrease in the share for each station (zero indicates a $100 \%$ decrease). It can be noticed that the stations Kopaonik, Niš, Zaječar, and Loznica are the most pronounced in terms of an increase, and a decrease is noticed at the stations Dimitrovgrad, Požega, and Smederevska Palanka.

Since uncertainty assessment is an important part of the analysis of the future climate projections, and considering that in this study the results of only one model are used, it is worth underlining that results from the EBU-POM model, for the future projections of annual and seasonal precipitation change are within, and close to the median of the multi-model ensemble results (MEP, 2017) from the ENSEMBLES project (Van der Linden and Mitchell, 2009). Consequently, presented results can be considered as a plausible realization of the changes in future precipitation regime, that is representative in terms to the other regional climate models results for the same scenario. 


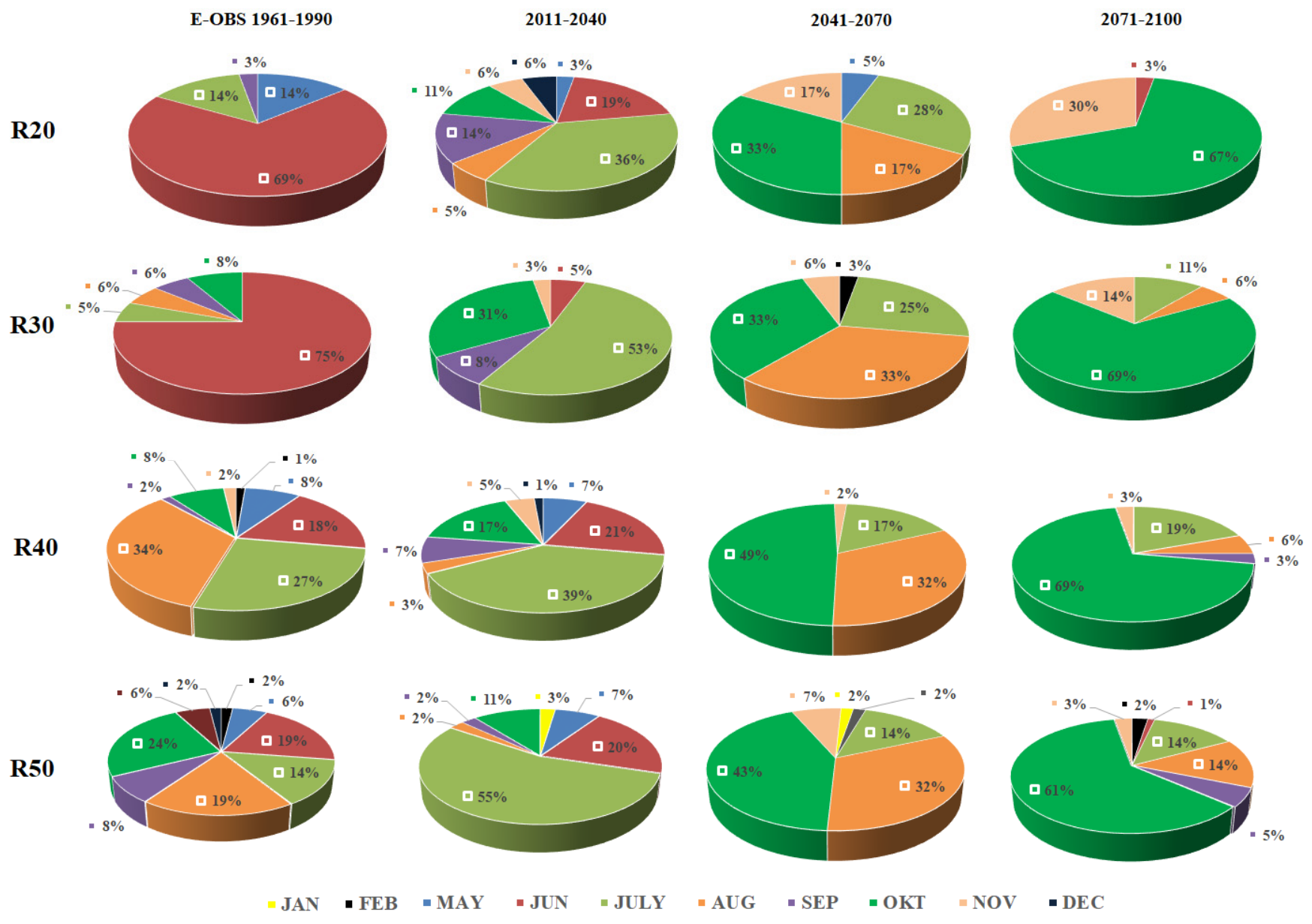

Fig. 9. Months with the largest number of days with precipitation amounts $\geq 20, \geq 30, \geq 40, \geq 50 \mathrm{~mm}$ for Central Serbia during the reference period and during the 21 st century.

Table 2. Changes of P20, P30, P40 and P50 during the three periods of the 21st century in relation to the period 1961-1990, expressed by their ratio.

\begin{tabular}{|c|c|c|c|c|c|c|c|c|c|c|c|c|}
\hline INDICES & \multicolumn{3}{|c|}{ P20 } & \multicolumn{3}{|c|}{ P30 } & \multicolumn{3}{|c|}{ P40 } & \multicolumn{3}{|c|}{ P50 } \\
\hline STATIONS & $\begin{array}{l}\stackrel{+}{+} \\
\stackrel{i}{1} \\
\overline{\vec{C}}\end{array}$ & 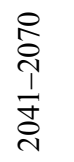 & $\frac{8}{\stackrel{8}{\pi}}$ & 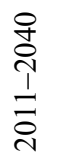 & 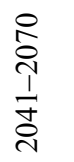 & 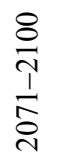 & $\begin{array}{l}\stackrel{P}{\stackrel{T}{T}} \\
\stackrel{i}{\vec{i}}\end{array}$ & 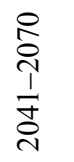 & $\frac{8}{\stackrel{8}{N}}$ & 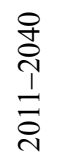 & 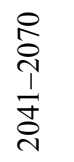 & 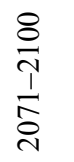 \\
\hline Beograd & 0.92 & 1.00 & 1.12 & 0.82 & 1.04 & 1.43 & 1.07 & 1.62 & 1.51 & 0.46 & 0.48 & 1.01 \\
\hline Ćuprija & 1.00 & 1.09 & 1.28 & 0.94 & 1.09 & 1.46 & 1.38 & 1.76 & 2.57 & 0.38 & 1.30 & 4.04 \\
\hline Crni Vrh & 1.11 & 1.08 & 1.26 & 1.08 & 1.22 & 1.65 & 1.60 & 1.38 & 2.48 & 1.14 & 1.14 & 2.39 \\
\hline Dimitrovgrad & 0.98 & 1.10 & 1.26 & 0.68 & 0.94 & 1.15 & 0.51 & 1.60 & 1.62 & 0.00 & 2.80 & 2.06 \\
\hline Kraljevo & 1.13 & 1.15 & 1.25 & 1.00 & 1.20 & 1.54 & 0.71 & 1.21 & 1.96 & 0.17 & 1.03 & 1.64 \\
\hline Kragujevac & 1.10 & 1.05 & 1.19 & 0.93 & 1.07 & 1.49 & 1.06 & 0.91 & 1.77 & 0.74 & 0.91 & 3.54 \\
\hline Kopaonik & 1.71 & 1.66 & 1.77 & 1.75 & 1.79 & 2.58 & 1.29 & 1.35 & 5.41 & 0.00 & 3.12 & 5.90 \\
\hline Kruševac & 1.29 & 1.40 & 1.53 & 1.24 & 1.69 & 1.73 & 1.93 & 1.66 & 2.97 & 1.12 & 1.80 & 4.41 \\
\hline Loznica & 1.29 & 1.13 & 1.27 & 1.62 & 1.48 & 1.58 & 1.69 & 1.97 & 2.21 & 2.34 & 2.40 & 1.98 \\
\hline Negotin & 1.12 & 1.05 & 1.45 & 1.20 & 0.93 & 1.70 & 1.33 & 1.27 & 2.42 & 1.12 & 1.00 & 2.57 \\
\hline Niš & 1.05 & 1.24 & 1.43 & 1.34 & 1.76 & 2.39 & 0.89 & 2.00 & 3.54 & 1.01 & 5.13 & 10.19 \\
\hline Požega & 0.95 & 0.97 & 1.26 & 0.74 & 1.15 & 1.56 & 0.20 & 1.92 & 2.26 & 0.00 & 1.33 & 4.09 \\
\hline S. Palanka & 1.20 & 1.15 & 1.26 & 1.14 & 1.23 & 1.60 & 0.79 & 0.72 & 1.74 & 0.00 & 0.68 & 1.79 \\
\hline Valjevo & 1.03 & 1.00 & 1.05 & 0.99 & 1.05 & 1.28 & 0.77 & 1.28 & 1.13 & 1.19 & 3.18 & 4.68 \\
\hline V. Gradište & 1.10 & 1.06 & 1.21 & 1.18 & 1.11 & 1.56 & 0.71 & 1.06 & 1.62 & 0.56 & 1.32 & 0.76 \\
\hline Vranje & 1.44 & 1.50 & 1.65 & 1.41 & 1.38 & 1.99 & 2.24 & 1.50 & 2.80 & 0.87 & 4.55 & 5.47 \\
\hline Zaječar & 1.12 & 1.14 & 1.82 & 1.11 & 1.18 & 2.58 & 0.97 & 1.38 & 2.81 & 0.00 & 2.36 & 3.29 \\
\hline Zlatibor & 1.13 & 1.09 & 1.28 & 1.30 & 1.15 & 1.65 & 0.78 & 1.22 & 1.78 & 0.27 & 1.83 & 1.63 \\
\hline
\end{tabular}



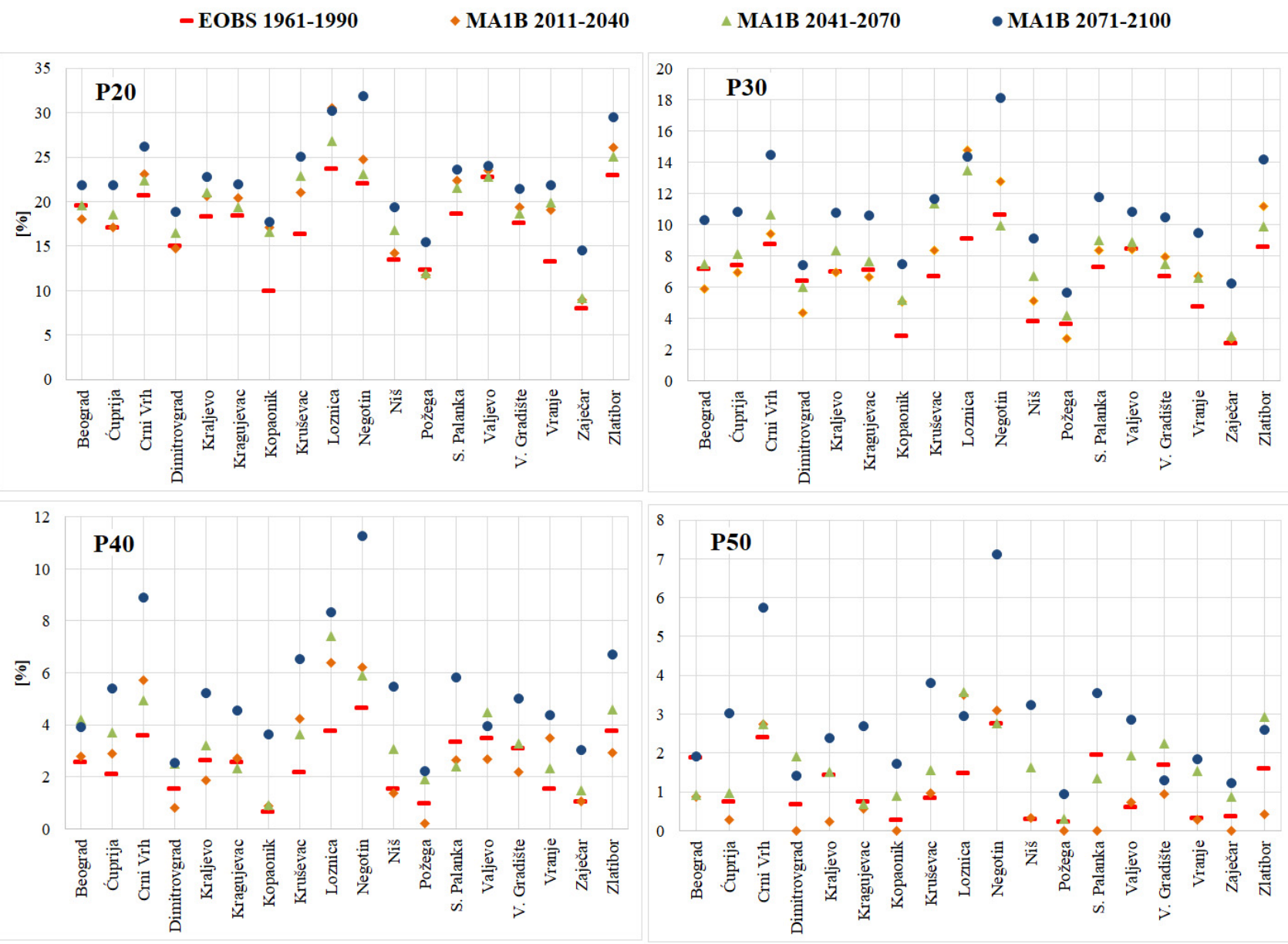

Fig. 10. The share of daily precipitation $\geq 20,30,40$ and $50 \mathrm{~mm}$ in the total annual precipitation in Central Serbia (\%); EOBS - E-OBS gridded climatology from European Climate Assessment \& Dataset (ECA\&D) project, MA1B - modelled values from the EBU-POM model projection for A1B scenario.

\section{CONCLUSION}

This study analyzed future changes in extreme precipitation in Central Serbia using regional climate simulation data obtained from the EBU-POM model under the SRES-A1B scenario. This analysis and other mentioned analyses for the area of Serbia and beyond, show that the climate changes during the 21 st century have significant impact on extreme precipitation. Therefore, the investigations of climate changes and their consequences are very important.

Within this analysis, the number of days with precipitation $\geq$ 20, 30, 40 and $50 \mathrm{~mm}$ (R20, R30, R40 and R50), their monthly distribution, and these precipitation shares in the annual precipitation amount are derived for 18 synoptic weather stations in Central Serbia. Results from the 2011-2040, 20412070 and 2071-2100 periods were compared to results from the reference period 1961-1990.

Consequently, changes are expected in the spatial distribution of R20, R30, R40 and R50. An increase of these indices is expected in the territory, where their minimum occurred during the reference period and vice versa. An increase in extreme precipitation is the most expected in the south of Central Serbia, where Kopaonik, Niš and Vranje stand out, as well as Loznica (west) and Zaječar (east). The increase of these indices is more pronounced compared to their decrease. The maximum increase was observed for R50, which is as much as $9 x$. In addition, it is noticed that with the precipitation amount increase the changes are more intense. The future decrease of extreme precipitation ranges from $10-100 \%$.

Changes in the monthly distribution of R20, R30, R40 and R50 are very similar for all indices. The time of occurrence of extreme precipitation in Central Serbia is gradually shifting towards the second part of a year. In the period 1961-1990, the most frequent occurrences of extreme precipitation were during June. Also, the occurrence of these events was more uncertain with the increase in the precipitation amount (they occur during several months in the year). In the period 2011-2040, extreme precipitation is expected to be the most frequent in July. In the middle of the 21 st century, they will mostly occur in August and October, and at the end of the 21st century, October is expected to be the month with the largest number of extreme precipitation events. In addition to that, in comparison with historical data, the uncertainty of the occurrence of extreme events will decrease (Figure 9).

In relation to the historical data, the average shares of these extreme precipitation events in the total annual precipitation will be increasing in the future. The increase is $1.2-2.4 \mathrm{x}$, except for P50 which is expected to decrease at the beginning of the 21 st century. The most noticeable stations are Kopaonik, Niš, Vranje, Zaječar and Loznica. Considering that these stations stood out in terms of an increase in R20, R30, R40 and R50, it was to be expected that they would be also stand out for other parameters as well. 
The summary of these results indicates that extreme precipitation in Central Serbia shifts spatially towards the south of the territory, and its time of occurrence is autumn (in the past it used to be summer). According to that, it is important to note that the climate and soil conditions are different, and this can significantly affect the processes of the hydrological cycle. Future work could be focused on the combining of these results with the analyses of the other hydrological cycle components. In this way, future changes in other hydrological cycle components, and also their joint effects will be determined. In accordance with them, the capacities for risk reduction and disaster risk management will be strengthened, as well as the integration of climate change adaptation practices in the analyzed area. The application of these analyses in many engineering sciences (civil engineering, agriculture, meteorology, etc.) would improve the practice and progress of these sciences. Research efforts such as this one are important for improving the regional climate model and for reducing the uncertainties in regional climate modeling.

Acknowledgements. The study is supported by the Ministry of Education, Science and Technological Development, Republic of Serbia, No. 43007. We acknowledge the E-OBS dataset from the EU-FP6 project UERRA (https://www.uerra.eu) and the Copernicus Climate Change Service, and the data providers in the ECA\&D project (https://www.ecad.eu).

\section{REFERENCES}

Aktar, N., 2013. Impact of climate change on riverbank erosion. International Journal of Sciences: Basic and Applied Research (IJSBAR), 7, 1, 36-42.

Alexander, L.V., Zhang, X., Peterson, T.C., Caesar, J. Gleason, B., Klein Tank, A.M.G., Haylock, M., Collins, D., Trewin, B., Rahimzadeh, F., Tagipour, A., Rupa Kumar, K., Revadekar, J., Griffiths, G., Vincent, L., Stephenson, D.B., Burn, J., Aguilar, E., Brunet, M., Taylor, M., New, M., Zhai, P., Rusticucci, M., Vazquez-Aguirre, J.L., 2006. Global observed changes in daily climate extremes of temperature and precipitation. Journal of Geophysical Research, 111, D05109. https://doi.org/10.1029/2005JD006290

Bocheva, L., Gospodinov, I., Simeonov, P. Marinova, T., 2010.Climatological analysis of the synoptic situations causing torrential precipitation events in Bulgaria during the period 1961-2007. In: Global Environmental Change: Challenges to Science and Society in Southeastern Europe, pp. 97-108.

Cavicchia, L., Scoccimarro, E., Gualdi, S., Marson, P., Ahren, B., Berthou, S., Conte, D., Aquila, A., Drobinski, P., Đurđević, V., Dubois, C., Gallardo, C., Li, L., Oddo, P., Sanna, A., Torma, C., 2018. Mediterranean extreme precipitation: a multi-model assessment. Climate Dynamics, 51, 901-913.

Cooper, R., 2019. Projection of future precipitation extremes across the Bangkok Metropolitan Region. Heliyon, 5, E01678.

Cornes, R., Van der Schrier, G., Van den Besselaar, E.J.M., Jones, P.D., 2018. An ensemble version of the E-OBS temperature and precipitation datasets. J. Geophys. Res. Atmos., 123. DOI: $10.1029 / 2017$ JD028200

Dawson, C.W., Abrahart, R.J., See, L.M., 2007. HydroTest: Aweb-based toolbox of evaluation metrics for the standardised assessment of hydrological forecasts. Environmental Modelling \& Software, 22, 1034-1052.

DeGaetano, A., Castellano, C., 2017. Future projections of extreme precipitation intensity-durationfrequency curves for climate adaptation planning in New York State. Climate Services, 5, 23-35.

Đurđević, V., 2010. Simulacija klime i klimatskih promena u jugoistočnoj Evropi korišćenjem regionalnog klimatskog modela. PhD Thesis. University of Belgrade, Belgrade, Serbia. (In Serbian.)

Đurđević, V., Rajković, B., 2008.Verification of a coupled atmosphere-ocean model using satellite observations over the Adriatic Sea. Annales Geophysicae, 26, 1935-1954.

Fotso-Nguemo, T., Diallo, I., Diakhate, M., Vondou, D., Mbaye, M., Haensler, A., Gaye, A., Tchawoua, C., 2019. Projected changes in the seasonal cycle of extreme rainfall events from CORDEX simulations over Central Africa. Climatic Change, 155, 339-357.

Gocić, M., Trajković, S., 2013.Spatiotemporal characteristics of drought in Serbia. Journal of Hydrology, 510, 110-123.

Gocić, M., Trajković, S., 2014. Spatio-temporal patterns of precipitation in Serbia. Theoretical and Applied Climatology, 117, 419-431.

Harpa, G.V., Croitoru, A.E., Đurđević, V., Horvath, C., 2019. Future changes in five extreme precipitation indices in the lowlands of Romania. International Journal of Climatology, 39, 5720-5740.

Hirabayashi, Y., Kanae, S., Emori, S., Oki, T. and Kimoto, M., 2008. Global projections of changing risks of floods and droughts in a changing climate. Hydrol. Sci. J., 53, 4, 754772.

Huang, G., Wang, X., Guo, J., Li, Y., Yang, L., 2018. Future changes in precipitation extremes over China projected by a regional climate model ensemble. Atmospheric Environment, 188, 142-156.

Janković, A., Podraščanin, Z., Đurđević, V., 2019. Future climate change impacts on residential heating and cooling degree days in Serbia. Időjárás, Quarterly Journal of the Hungarian Meteorological Service, 123, 351-370.

Jiang, Z., Song, J., Li, L., Chen, W., Wang, Z., Wang, J., 2012. Extreme climate events in China: IPCC-AR4 modelevaluation and projection. Climatic Change, 110, 385-401.

Jovanović, S., Anđelković, G., Manojlović, S., Samardžić, I., Živković, Lj., Šabić, D., Gatarić, D., Džinović, M., 2018. Extreme precipitation events in Serbia: Defining the threshold criteria for emergency preparedness. Atmosphere, 9, 5, 188.

Kjellström, E., Ruosteenoja, K., 2007. Present-day and future precipitation in the Baltic Sea region as simulated in a suite of regional climate models. Climatic Change, 81, 281-291.

Kramer, K., Ware, J., 2019. Counting the cost: 2019: a year of climate breakdown. Christian Aid, London, United Kingdom.

Kržič, A., Tošić, I., Đurđević, V., Veljović, K., Rajković, B., 2011. Changes in climate indices for Serbia according to the SRES-A1B and SRES-A2 scenarios. Climate Research, 49, 73-86.

Li, L., Yao, N., Liu, D.L., Song, S., Lin, H., Chen, X., Li, Y., 2019. Historical and future projected frequency of extreme precipitation indicators using the optimized cumulative distribution functions in China. Journal of Hydrology, 579, Article Number: 124170.

MEP, 2017. Second National Communication of the Republic of Serbia under the United Nations Framework Convention on Climate Change. Ministry of Environmental Protection of the Republic of Serbia, Belgrade, Serbia, $162 \mathrm{p}$. http://www.klimatskepromene.rs/wpcontent/uploads/2017/09/SNC_eng.pdf 
Mihailović, D., Drešković, N., Arsenić, I., Ćirić, V., Đurđević, V., Mimić, G., Pap, I., Balaž, I., 2016. Impact of climate change on soil thermal and moisture regimes in Serbia: An analysis with data from regional climate simulations under SRES-A1B. Science of the Total Environment, 571, 398-409.

Nakicenovic, N., Swart, R. (Eds.), 2000. Special Report on Emissions Scenarios. A Special Report of Working Group III of the Intergovernmental Panel on Climate Change. Cambridge University Press, Cambridge, United Kingdom and New York, NY, USA.

Pongracz, R., Bartholy, J., Miklos, E., 2011. Analysis of projected climate change for Hungary using ensembles simulations. Applied Ecology and Environmental Research, 9, 4, 387-398.

Republic Hydrometeorological Service of Serbia, 2020. Precipitation regime in Serbia. Retrieved May 3, 2020. http://www.hidmet.gov.rs/eng/meteorologija/klimatologija_ padav_rezim.php

Schneider, C., Laize, C.L.R., Acreman, M.C., Florke, M., 2013. How will climate change modify river flow regimes in Europe? Hydrol. Earth Syst. Sci., 17, 325-339.

Soltani, M., Laux, P., Kunstmann, H., Stan, K., Sohrabi, M.M., Molanejad, M., Sabziparvar, A.A., SaadatAbadi, A., Ranjbar, F., Rousta, I., Zawar-Reza, P., Khoshakhlagh, F., Soltanzadeh, I., Babu, C.A., Azizi G.H., Martin, M.V., 2016. Assessment of climate variations in temperature and precipi- tation extreme events over Iran. Theoretical and Applied Climatology, 126, 775-795

Tan, X., Gan, T., Shao, D., 2017. Effects of persistence and large-scale climate anomalies on trends and change points in extreme precipitation of Canada. Journal of Hydrology, 550, 453-465.

Tramblay, Y., Somot, S., 2018. Future evolution of extreme precipitation in the Mediterranean. Climatic Change, 151, 289-302.

Unkašević, M., Tošić, I., 2011. A statistical analysis of the daily precipitation over Serbia: trends and indices. Theoretical and Applied Climatology, 106, 69-78.

Van der Linden P., Mitchell, J.F.B. (eds.), 2009. ENSEMBLES: Climate change and its impacts: Summary of research and results from the ENSEMBLES project. Met Office Hadley Centre, FitzRoy Road, Exeter EX1 3PB, UK. 160p.

Vuković, A., Vujadinović, M., Rendulić, S., Đurđević, V., Ruml, M., Babić, V., Popović, D., 2018. Global warming impact on climate change in Serbia for the period 19612100.Thermal Science, 22, 2267-2280.

Yang, Z., Gao, X., Guo, M., Zhu, Q., Xu, Z., Gao., K., 2020. Temperature dependence of extreme precipitation over mainland China. Journal of Hydrology, 583, 1245.

Received 16 October 2020 Accepted 3 February 2021 